\title{
Technology mapping and adoption behaviour for sugarcane protection technologies by Dharmapuri District Sugarcane growers
}

\author{
C. Karpagam* \\ Central Institute for Cotton Research, Regional Station, Coimbatore - 641003 (Tamil \\ Nadu), India \\ M. K. Selvam \\ Sugarcane Breeding Institute, Coimbatore - 641041 (Tamil Nadu), India \\ P. Mooventhan \\ National Institute of Biotic Stress Management, Raipur - 493225 (Chhattisgarh), India
}

${ }^{*}$ Corresponding author. E-mail: karpsicar@gmail.com

\begin{abstract}
Sugarcane is the second most important industrial crop in the country occupying about 5 million hectares of area with the production of $376.9 \mathrm{mt}$. Although more than $40 \%$ of the cane area in the country is in Uttar Pradesh, Tamil Nadu ranks first in productivity of sugarcane. Even though Tamil Nadu is in higher productivity zone, the average farm level potential yield was very less which leads lot of scope for increasing production in Tamil Nadu. Sugarcane farmers from Tamil Nadu ranged from small to large. All the farmers not following all the recommended practices. Hence, a study is required to analyses the predominant technologies in the particular area and adoption behavior of the farmers to bridge the technological gap. With that idea in mind, a study has been taken up with the objectives that to document the technological mapping and to study the adoption behavior of sugarcane farmers at Subaramani Siva Co-operative Sugar Mill area in Dharmapui district of Tamil Nadu state. From Dharmapuri districts seven blocks were selected. From each block ten respondents were selected; thus 70 respondents were constituted for the study. The Study revealed that all the blocks are not similar in case of technologies, the predominant technologies are differing block to block. Adoption pattern for protection technologies reveled that integrated weed management was adopted by majority of the respondent. The technologies 'pheromone trap' and 'soil trenching of recommended termiticides' are not at all adopted by the respondents in the study area.
\end{abstract}

Keywords: Adoption, Full adoption, Not adoption, Partial adoption, Technological Mapping and Yield gap

\section{INTRODUCTION}

India is the second largest producer of sugar, our export share is marginal due to large domestic demands. Sugarcane plays a vital role in agricultural growth rate. Sugarcane is the second most important industrial crop in the country occupying about 5 million hectares of area with the production of $376.9 \mathrm{mt}$ which support the production of $32.38 \mathrm{mt}$ of sugar (Anonymous, 2019). About 5 million farmers are involved in the cultivation of sugarcane and sugar industry contributes significantly to the rural economy by providing employment for nearly $4 \%$ of the rural population directly or indirectly (Anonymous, 2015). Even though Tamil Nadu is in higher productivity zone, the average farm level potential yield was very less which leads lot of scope for increasing production in Tamil Nadu. Sugarcane farmers from Tamil Nadu ranged from small to large. The diverse climatic condition and socio-economic conditions of the sugarcane farmers demand cost effective technologies. All the farmers are not following all the recommended practices and in every place we can't observe the uniform technologies. Hence, a study was required to study the technological mapping and the adoption behaviour of the farmers to bridge the technological gap. With that idea in mind, a study has been taken up with the following objectives: i) To prepare technology mapping for sugarcane technologies in Subramaniya Siva Cooperative Sugar Mill area of Dharmapuri district, ii) To study the adoption pattern for protection technologies of sugarcane farmers in Subramaniya Siva Cooperative Sugar Mill area of Dharmapuri district. 


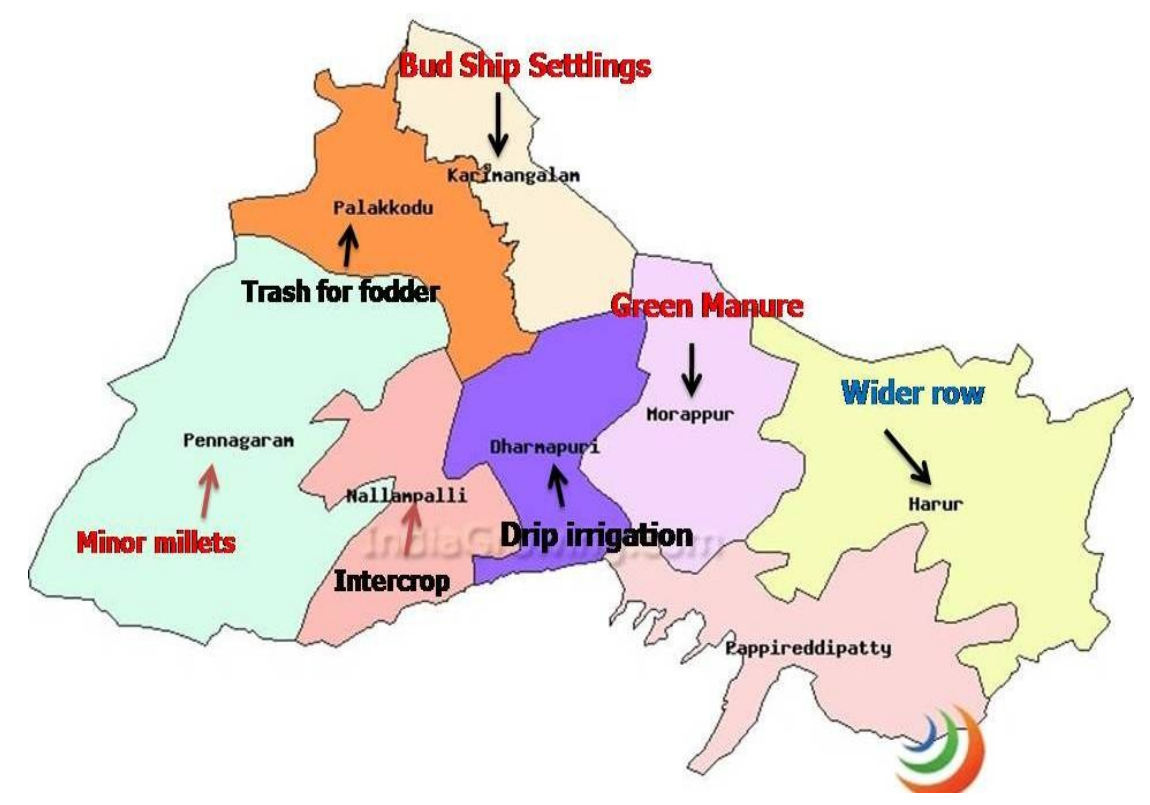

Fig. 1. Block wise technology mapping for sugarcane in Dharmapuri District.

\section{MATERIALS AND METHODS}

District Dharmapuri was selected for the research since it has significant area under sugarcane cultivation. Seven blocks and ten farmers from each block were selected as study area and respondents respectively (Fig.1). Subaramani Siva Cooperative Sugar Mill is the technological backstopping source for the farmers in the study area. The value of the study largely depends upon the different variables taken into consideration for the study. For technological mapping, predominant technologies prevailing in the block were considered. For adoption study different protection technologies viz., sett treatment, healthy planting material usage, chemicals for Early Shoot Borer (ESB), Trichogramma for Internode Borer (INB), Pheromone trap for INB, Change of lure, White grub beetle collection, termiticides trenching and Integrated Weed management (IWM) were selected. The methodology followed by Karpagam et.al
(2019) was adopted for the study. Focused group discussion (FGD), Personal interview method and observation methods were followed to collect the information from the respondents.

\section{RESULTS}

The Technological mapping pave the way to understand the predominant technologies prevailed in the study area which in turn helps to sugar mill and policy maker to restructure their extension strategies for the particular area. Adoption behavior of protection technologies gives the ideas about the technologies reached farmers and technologies not yet reached farmers. Hence, these two dimensions gives holistic view about the cane cultivation in the particular area.

Technology mapping: It could be observed from Table 1 that each block was different in technology predominance based on the local condition. Dharmapuri block is low rainfall area; hence it was

Table 1. Block wise technology mapping for sugarcane in Dharmapuri district.

\begin{tabular}{|c|c|}
\hline Dharmapuri & $\begin{array}{l}\text { To overcome the severe drought, drip irrigation is the predominant technology in this district. } \\
\text { Country plough is common implements for making ridges and furrows }\end{array}$ \\
\hline Palakkodu & $\begin{array}{l}\text { Using cane trash as fodder for cattle is the predominant technology in this block. } \\
\text { After harvesting, the top portion will be collected by the labourers and selling in local market } \\
\text { as cattle feed and getting good income out of it. It gives additional income to the labourers. }\end{array}$ \\
\hline Nallampalli & Onion and tomato were cultivated as intercrop in sugarcane. \\
\hline Karimangalam & $\begin{array}{l}\text { Bud chip settlings and single bud settlings are getting popular in this block. } \\
\text { Drip irrigation was adopted by more than } 30 \% \text { of the registered cane area }\end{array}$ \\
\hline Morappur & $\begin{array}{l}\text { Due to severe drought farmers are shifting to Tapiocca cultivation in this block. } \\
\text { Cultivation of green manure crop as cover crop is predominantly practiced. }\end{array}$ \\
\hline Harur & $\begin{array}{l}\text { Poultry manure was the predominantly used in this district. Press-mud was mixed with FYM. } \\
\text { Wider row and drip irrigation technologies were getting momentum in this block. }\end{array}$ \\
\hline Pennagaram & $\begin{array}{l}\text { It is one of the low rainfall blocks in Dharmapuri district. Minor millets are the predominant } \\
\text { crops in this block. }\end{array}$ \\
\hline
\end{tabular}




\section{Protection technologies}

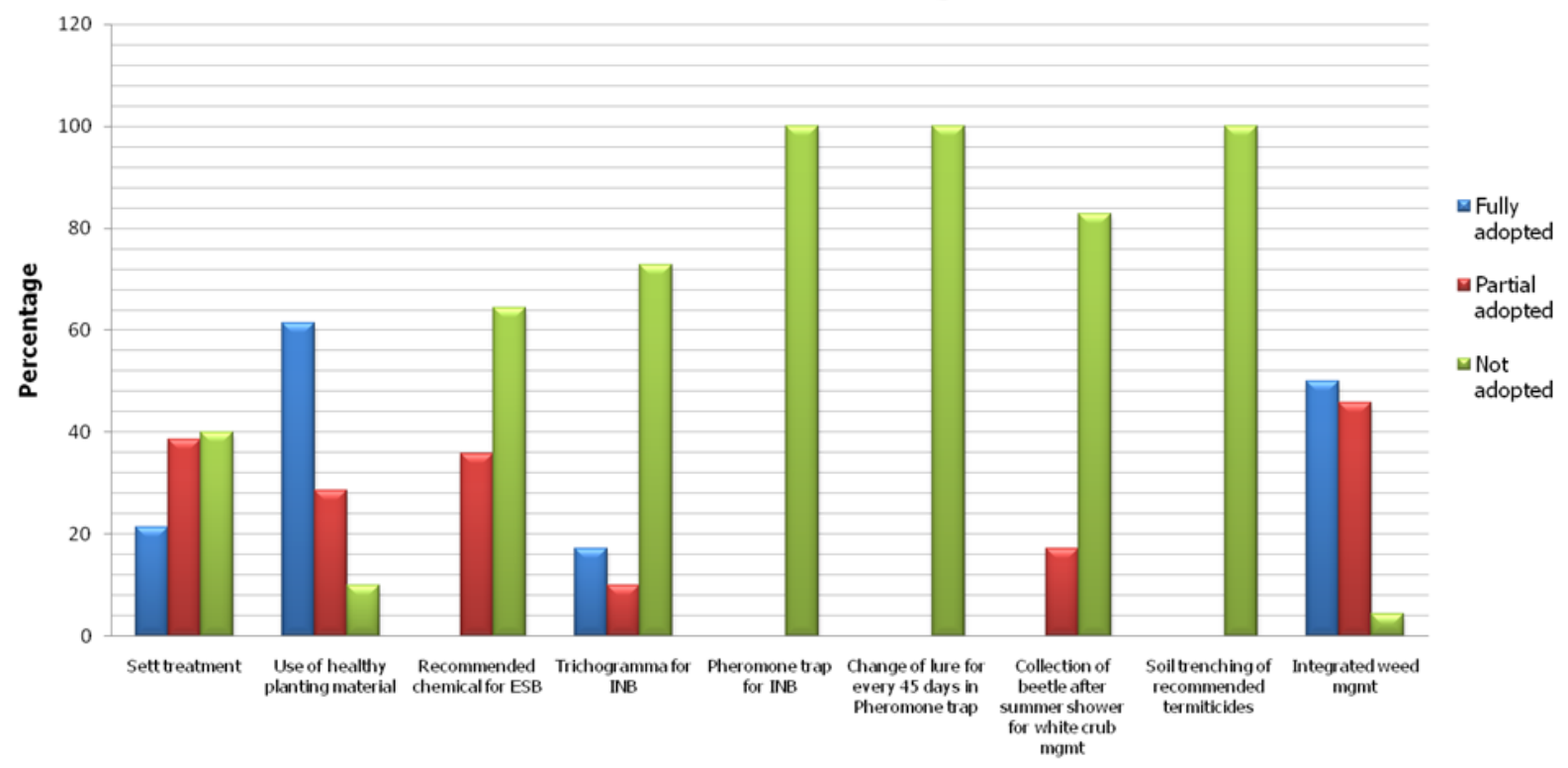

Fig. 2. Adoption pattern of sugarcane farmers for protection technologies in Dharmapuri district.

observed that the predominance technology in the block was 'Drip irrigation". Palakkodu block was predominant with the practice that cutting and selling the top portion of harvested cane as fodder in local market. It may be due to that this particular block was dominated with majority labours category. The income from the particular practice may be an additional income for their livelihood. In Nallampalli block intercrop in sugarcane was predominant technology which followed by the majority of the cane growers. The predominant technologies in Kariyamangalam block were Sustainable Sugarcane Initiatives (SSI) along with bud chip settling and drip irrigation. This block had 358 numbers of tube/bore wells and 7114 ordinary wells (Technical report of central ground water board, 2009). These may be the reasons for predominance of drip irrigation on the particular block. Cultivation of green manure crop as cover crop was predominantly practiced in Morappur block. Wider row and drip irrigation technologies were getting momentum in Harur block due to SSI up scaling methods. This block was also famous for tube/bore wells (574) and ordinary wells (12767) (Technical report of central ground water board, 2009). Hence the drip irrigation technology was predominant in this block as well. Pennagram is economically backward block and predominantly occupied by small farmers and labours, the major crop in the particular block was minor millets.

Adoption behaviour for protection technologies in Dharmapuri district: It can be observed from Table 2 and Fig. 2 that healthy planting material was the practice adopted by majority $(61.43 \%)$ of the respondents in the study area. Use of healthy planting material is not required any additional cost. Hence, the practice was followed by the majority of the respondents without additional cost of cultivation. Integrated weed management was the next technology adopted by the majority $(50 \%)$ of the respondents. During the survey it was observed that weed was the major problem in the study area.

Further, farmers undertaking hand weeding and chemical weeding to manage the weed problem. These findings were in accordance with the study

Table 2. Adoption pattern of sugarcane farmers for protection technologies in Dharmapuri district. $(\mathbf{n}=\mathbf{7 0})$

\begin{tabular}{lllllll}
\hline \multirow{2}{*}{ Protection technologies } & \multicolumn{3}{l}{ Fully adopted } & \multicolumn{2}{l}{ Partial adopted } & \multicolumn{2}{l}{ Not adopted } \\
\cline { 2 - 7 } & No & $\%$ & No & $\%$ & No & $\%$ \\
\hline Sett treatment & 15.00 & 21.43 & 27 & 38.57 & 28.00 & 40.00 \\
Use of healthy planting material & 43.00 & 61.43 & 20 & 28.57 & 7.00 & 10.00 \\
Recommended chemical for ESB & 0.00 & 0.00 & 25 & 35.71 & 45.00 & 64.29 \\
Trichogramma for INB & 12.00 & 17.14 & 7 & 10.00 & 51.00 & 72.86 \\
Pheromone trap for INB & 0.00 & 0.00 & 0 & 0.00 & 70.00 & 100.00 \\
Change of lure for every 45 days in Pheromone trap & 0.00 & 0.00 & 0 & 0.00 & 70.00 & 100.00 \\
Collection of beetle after summer shower for white & 0.00 & 0.00 & 12 & 17.14 & 58.00 & 82.86 \\
crub mgmt. & 0.00 & 0.00 & 0 & 0.00 & 70.00 & 100.00 \\
Soil trenching of recommended termiticides & 35 & 50.00 & 32.00 & 45.71 & 3 & 4.29 \\
Integrated weed management & & & & & & \\
\hline
\end{tabular}


of Karpagam et al., (2019) in Cuddalore district reported that the technologies viz., Integrated Weed Management $(85.00 \%)$, use of healthy planting material $(83.33 \%)$ were fully adopted by more than 80 per cent of the respondents in the study area. Further, this result was in contrary with Peiris et al., (2009) reported that Sugarcane lands were highly dominated by several types of weeds. Therefore they compete with sugarcane plants as well as act as a host plant for pests and diseases and weed management was well adopted by $14 \%$ of farmers due to the poor knowledge and high cost of weedicides. The other technologies had either partial adoption or non-adoption. Unlike private factories, this co-operative sugar factory not supplying Tricho card to the farmers. Farmers have to purchase Tricho card by their own. Therefore, the practice got lesser adoption $(17.14 \%)$. This finding in not on bar with the finding of Karpagam et al., (2019) while studying the adoption behavior of cane protection technologies in Cuddalore district reported that Tricho cards were supplied by the sugar mill to the farmers at nominal rate, hence the adoption rate was higher for the particular technology. In case of chemical control for Early Shoot borer (ESB), majority of the farmers not applying any insecticide and only $35.71 \%$ of the respondents applying chemicals for ESB but not as per the recommendation. The technologies 'pheromone trap' and 'soil trenching of recommended termiticides' are not at all adopted by the respondents in the study area.

\section{Conclusion}

Sugarcane is an important commercial crop; technological mapping and adoption behaviour analysis will pave the way for yield improvement. Hence the present study clearly explored that use of healthy planting material was adopted by more than $60 \%$ of the respondents followed by Inte- grated weed management. Further, Technological mapping clearly brought out the predominant technologies prevailed in block wise. These findings will certainly helpful to the extension workers, researchers and sugar factory personnel to reorient their extension strategies for cane technology transfer and to reduce the yield gap in the study area.

\section{REFERENCES}

1. Anonymous (2015). Vision 2050, retrieved from http:// www.sugarcane.res.in/images/sbi/article/ sbi_vision_2050.pdf. Sugarcane Breeding Institute, Coimbatore, India.

2. Anonymous (2019). Sugarcane and molasses production at a glance. Cooperative sugar. 50 (7):45

3. Karpagam, C., PuthiraPrathap, D and Moovendhan, P. (2016). Farmer led gross root level entrepreneurial initiatives for sustainable sugarcane production system in Tamil Nadu, India. Journal of Applied and Natural Science, 8(4).

4. Karpagam, C., Selvaraj, T., Mooventhan, P and Venkatasubramanian, V. (2019). Social and technological dimensions; and constraint analysis in sugarcane cultivation of Theni district of Tamil Nadu, India. Journal of Applied and Natural Science, 11(2): 581-586. DOI:10.31018/jans.v11i2.2102.

5. Karpagam, C., Udayakumar, $\mathrm{N}$ and Mooventhan, $\mathrm{P}$ (2019). Social dimension and adoption behaviour of sugarcane production and protection technologies among sugarcane farmers in coastal district of Cuddalore in Tamil Nadu, India. Indian Journal of Natural Sciences. 10(56): $17687-17693$.

6. Peiris, T.D.G., Abeynayake, N. R and Perera, M. S. (2009). Socio - economic factors affecting the technology adoption level of sugarcane in rainfed sector in Sevenagala. J. Food Agric.2:22-27. DOI:http:// dx.doi.org/10.4038/jfa.v2i2.4177

7. Ramasubramanian, $T$ and Karpagam,C. (2014). FAQs on early shoot borer, Kissan world, 41(9):19-21

8. Technical Report series, (2009). District Groundwater brochure, Dharmapuri District, Tamil Nadu. Central Groundwater Board, Ministry of Water resources, Government of India. 